a.m. My first thought, viewing the bird with a pair of $8 \times 42$ Pentax roof prism binoculars, was a pigeon. The bird resembled a Rock Dove in the grey plumage, but with yellow feet and yellow black-tipped bill. Edging closer, I viewed the bird for about 10 minutes from $10 \mathrm{~m}$, noting the iridescence behind the head down on to the back, white line between iridescence and greyish-purple head, darker wings, grey body and tail with a noticeable darker grey band in the tail. I thought ...B and-tailed Pigeon?

Not sure of the field marks, I hustled back to the cabin where the bird books were waiting. I looked through: Birds of North America, National Geographic Society; Birds of North America 1st ed. by Robbins et al. and Field Guide to Western Birds 3rd ed. by Peterson. These all confirmed that what I had seen was a Band-tailed Pigeon, a lifer, a long way from home given the range maps.

I set out again with a camera. Julie and Jeffrey, wife and son, back from a round of golf, also viewed the bird, now sitting sleepily in the shade in a White Birch. They both saw the field marks of yellow bill with a black tip and yellow feet, white stripe on back of head and band in the tail and compared the bird to one of the field guides. My two photographs, with a $50 \mathrm{~mm}$ lens at $50 \mathrm{~m}$ were disappointing. Several unsuccessful attempts were made to find the Band-tailed $\mathrm{Pi}$ geon until 11 August 1995 when we left Marean Lake.

Don Hooper does not list Bandtailed Pigeon in the Birds of EastCentral Saskatchewan. This sighting adds a new species to the area. There have been ten additional sightings in Saskatchewan as reported in the seventh edition, Field
Checklist of Saskatchewan, October 1990. This sighting is the most northeasterly record within Saskatchewan to date.

- Ron Jensen, 849 - 10th Avenue North

East, Swift Current, SK. S9H 2T6

\section{PARTIAL ALBINO MAGPIE}

The grey and white Black-billed Magpie pictured below became a common visitor in the vicinity of the yard of Alec and Laila Johnson, two miles south of Archerwill throughout the summer and fall of 1995.

- Elaine Hughes, Box 309, Archerwill, SK. SOE OBO

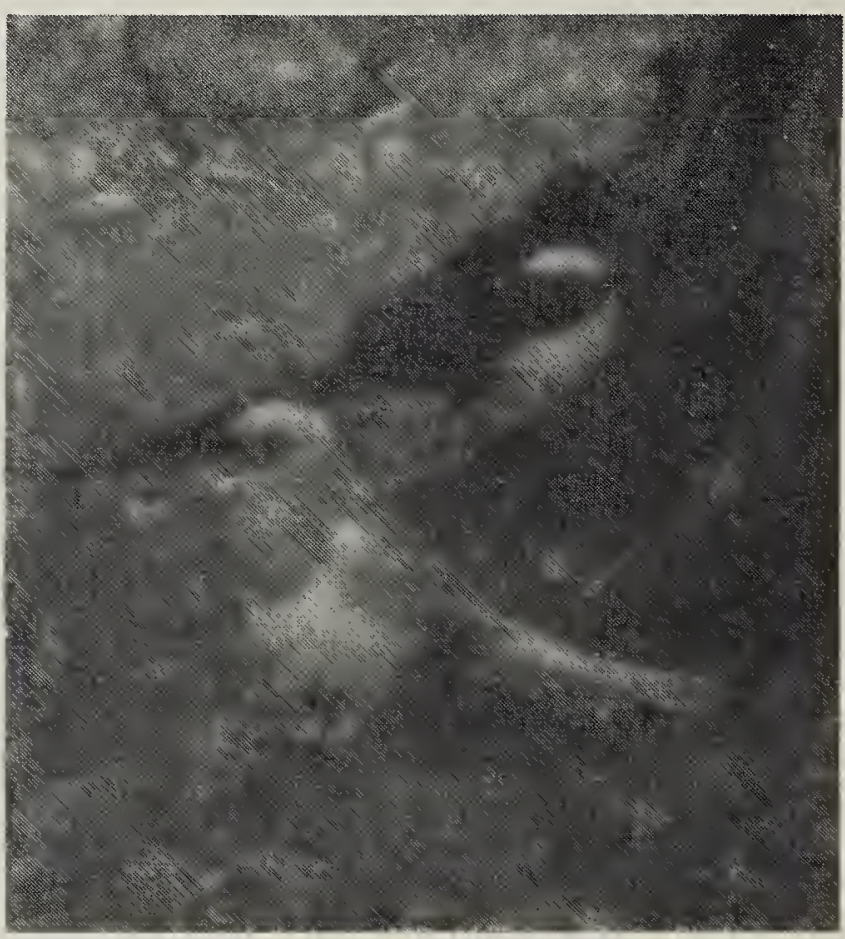

Partial Albino Magpie Elaine Hughes

\section{FOXES IN SOUTH-CENTRAL SASKATCHEWAN}

My father, Knut Jordheim homesteaded some 40 miles north of Swift Current, approximately 2 miles north of the South Saskatchewan River in 1908. I remember him mentioning "kit foxes" that would chew harnesses if left on the ground overnight. I presume these were actually Swift Foxes. 